\title{
Analisis Kemampuan Calon Guru IPA Mengintegrasikan Teknologi Dalam Pembelajaran Menggunakan SAMR
}

\author{
Dudung Abdurrahman a, 1*, Nursafitri ${ }^{\text {b, } 2}$ \\ ${ }^{a}$ Prodi Pendidikan IPA Universitas Garut, Jalan Raya Samarang No. 52 A, Garut 44151

 \\ dudungabdurrahman@uniga.ac.id*; Nursafit269@gmail.com, \\ *korespondensi penulis
}

ARTICLE HISTORY

Revised: 7 February 2022

Accepted: 14 February 2022

\begin{abstract}
ABSTRAK
Pembelajaran di masa pandemi Covid 19 mengharuskan guru memiliki kemampuan dalam teknologi untuk mendukung pembelajaran. Pembelajaran model ini menjadi new normal dalam pendidikan. Oleh karena itu, calon guru harus memiliki kemampuan mengintegrasikan teknologi dalam pembelajaran. Penelitian ini bertujuan untuk menganalisis kemampuan calon guru IPA dalam mengintergasikan teknologi dalam pembelajaran IPA. Metode penelitian yang digunakan adalah deskriptif. Sampel pada penelitian ini adalah mahasiswa yang mengikuti perkuliahan microteaching semster ganjil 2021/2022 sebanyak 6 orang. Pofil kemampuan calon guru IPA dalam mengintegrasikan teknologi diperoleh dari observasi pembelajaran yang disimulasikan. Tingkatan integrasi teknologi dalam pembelajaran dikelompokan menggunakan SAMR. Hasilnya diperoleh bahwa mahasiswa calon guru IPA dalam mengintegrasikan pembelajaran masih berada pada tingkat subtitution. Pada tingkat ini, teknologi digunakan pada pembelajaran hanya sebatas pengganti dan tidak ada peningkatan fungsional teknologi di pembelajaran.
\end{abstract}

Kata kunci: SAMR, Teknologi, Pembelajaran Daring

ABSTRACT

Teachers must be able to use technology to support learning in the event of pandemic's Covid-19. In education, this learning style has become the new norm. As a result, pre-service teachers must be able to integrate technology into their classrooms. The aim of this study is to assess pre-service science teachers' abilities to integrate technology into science instruction. The descriptive research method was applied. This study used a sample of six students who took microteaching courses in the odd semester of 2021/2022. Simulated learning observations were used to create a profile of potential science teachers' ability to integrate technology. SAMR is used to categorize the degree to which technology is integrated into learning. As a result, future science instructors who are interested in integrating learning are still at the substitution level. At this level, technology used in learning is only a substitute, and there is no functional improvement in learning technology.

Key word: SAMR, Techonology, Online Learning

\section{Pendahuluan}

Pandemi Covid-19 di akhir tahun 2019 yang melanda dunia telah membuat perubahan di berbagai sektor termasuk dalam dunia pendidikan. Pemerintah Indonesia membuat kebijakan adanya pandemi ini pada bidang pendidikan dengan mengkondisikan proses pembelajaran tidak dilakukan secara tatap muka. Kegiatan pembelajaran tatap muka otomatis berhenti dikarenakan kebijakan ini. Pilihan solusi yang tepat untuk keadaan ini agar pembelajaran dapat berlanjut adalah pembelajaran daring (Elliniawati, et al., 2021). Pembelajaran daring adalah pembelajaran yang menggunakan media internet dengan aksesibilitas, konektivitas dan fleksibilitas yang menghasilkan berbagai jenis interaksi siswa dengan guru dan sumber belajar (Muliadi, et.al., 2021). Pada pembelajaran daring guru diharapkan mampu untuk merancang dan mengimplementasikan inovasi pembelajaran menggunakan media online (Nurmalahayati, 2022). Pembelajaran daring diharapkan menjadi momentum untuk membuat pembelajaran inovatif berbasis teknologi (Muliadi, et.al., 2021).

Pada pandemi ini, pengetahuan tentang teknologi menjadi hal wajib bagi guru. Teknologi yang dimaksud disini adalah teknologi yang dapat membantu guru merepresentasikan konsep, prinsip, dan hukum (Juanda, et.al.,2021). Teknologi dianggap menjadi media yang efektif dalam mengemas pesan (informasi) sehingga peserta didik mudah mengolahnya (Suminar, 2019). Integrasi teknologi dalam 
pembelajaran sejalan dengan pembelajaran abad 21 yang melatihkan kemampuan literasi teknologi (Effendi \& Wahidy, 2019).

Integrasi teknologi dalam pembelajaran bukan hal yang baru (Purnasari \& Sadewo, 2020). Beberapa penelitian telah dilakukan untuk mengetahui dampak dari integrasi teknologi dalam pembelajaran. Ahmad, $\mathrm{N}$ et al. (2021) melakukan penelitian dengan mengintegrasikan animasi dan simulasi komputer pada materi elektrokimia. Hasilnya kelas yang menggunakan animasi dan simulasi komputer memperoleh pemahaman yang lebih baik dari skor tes dan motivasi dalam belajar kimia. Chaeroni, Y et al. (2019) menerapkan $i$-spring suite 8 dalam pembelajaran matematika. hasilnya terdapat peningkatan kemampuan peserta didik memahami dan memecahkan masalah matematis.

Teknologi telah membawa tantangan baru bagi guru dalam mengembangkan pembelajaran (Juanda et.al., 2021). Untuk dapat mengembangkan pembelajaran berbasis teknologi maka guru perlu mengembangkan kompetensinya (Purnasari \& Sadewo, 2020). Peningkatan kompetensi guru dapat meningkatkan inovasi pembelajaran yang dibuatnya (Effendi \& Wahidy, 2019). Peningkatan kualitas pembelajaran dengan berbasis teknologi diharapkan dapat menghasilkan sumber daya manusia yang unggul sesuai dengan kebutuhan di masanya (Nuryani \& Handayani, 2020).

Pengukuran tingkat integrasi teknologi dalam pembelajaran dapat menggunakan model SAMR (Zainal,2020). Model SAMR merupakan model yang sederhana tetapi dapat menggambarkan proses integrasi teknologi ke dalam pembelajaran secara komprehensif (Muktiarni, 2021). Model ini menggunakan hirarki yang menggambarkan tingkatan kognitif yang dapat dicapai dengan menggunakan teknologi sebagai media belajar (Savignano,2017). Model SAMR direpresentasikan seperti tangga yang menunjukkan tingkatan integrasi teknologi dalam pembelajaran (Niswatin \& Zainiyati, 2020). Tingkatan SAMR dideskripsikan seperti Tabel 1. Tingkatan subtitution, teknologi bertindak sebagai alat, aktivitas pada pembelajaran tatap muka. Pada tingkatan augmentation, teknologi masih sebagai alat pengganti pembelajaran tatap muka tetapi lebih efisien dengan adanya keuntungan bagi siswa maupun guru (Hunter, 2015). Pada tingkatan modification, strategi pembelajaran disesuaikan dengan tujuan penggunaan teknologi sehingga menghasilkan pengalaman baru yang tidak diperoleh pada pembelajaran tatap muka, serta tahap redefinition memberikan kesempatan bagi guru dan siswa untuk merekonstruksi pendidikan sehingga dapat memenuhi kebutuhan pada pembelajaran digital (Muktiarni, 2021). Berdasarkan uraian di atas, penelitian ini bertujuan menganalisis kemampuan calon guru menggunakan teknologi dalam pembelajaran daring dengan menggunakan kerangka SAMR.

\section{Metode}

Metode penelitian yang digunakan adalah deskriptif. Kemampuan calon guru IPA dalam mengintegrasikan teknologi menjadi fenomena yang akan dideskripsikan pada penelitian ini. Sampel pada penelitian ini sebanyak 6 orang yang mengikuti mata kuliah microteaching. Subjek telah mengambil mata kuliah dasar-dasar komputer untuk pembelajaran IPA (e-learning). Integrasi teknologi dalam pembelajaran yang disimulasikan oleh calon guru IPA dianalisis menggunakan SAMR. Definisi SAMR yang digunakan pada penelitian ini menurut Puendedura (2014) dan dijabarkan pada Tabel 1.

Tabel 1. SAMR

\begin{tabular}{ll}
\hline Kategori & \multicolumn{1}{c}{ Definisi } \\
\hline Subtitution & $\begin{array}{l}\text { Teknologi bertindak sebagai alat pengganti, } \\
\text { tanpa adanya perubahan fungsional }\end{array}$ \\
Augmentation & $\begin{array}{l}\text { Teknologi bertindak sebagai alat pengganti, } \\
\text { dengan adanya peningkatan fungsional }\end{array}$ \\
Modification & $\begin{array}{l}\text { Teknologi memungkinkan untuk mendesain } \\
\text { ulang tugas secara signifikan }\end{array}$ \\
Redifinition & Teknologi memungkinkan membuat tugas baru, \\
& yang sebelumnya tidak terbayangkan \\
\hline
\end{tabular}




\section{Hasil dan Pembahasan}

Subjek memiliki kesempatan untuk menampilkan pembelajaran yang telah dirancangnya pada saat ujian microteaching secara daring melalui aplikasi zoom. Integrasi teknologi dalam pembelajaran pada setiap subjek dideskripsikan melalui Tabel 2.

Tabel 2. Intergrasi Teknologi Dalam Pembelajaran Setiap Calon Guru

\begin{tabular}{|c|c|}
\hline Subjek & Integrasi Teknologi \\
\hline & $\begin{array}{l}\text { - Penggunaan power point sebagai media penyampaian materi. Informasi berupa } \\
\text { gambar dan teks (subtitution) }\end{array}$ \\
\hline A & $\begin{array}{l}\text { - Penggunaan aplikasi simulasi untuk pengalaman menggunakan alat ukur (virtual), } \\
\text { dan dapat mengetahui pembacaan sudah benar atau belum (augmentation) } \\
\text { - Menggunakan aplikasi quizizz untuk mengevaluasi pertemuan (subtitution) }\end{array}$ \\
\hline B & $\begin{array}{l}\text { - Penggunaan power point sebagai media untuk menyampaikan materi. Informasi } \\
\text { berupa gambar dan teks (subtitution) } \\
\text { - Penggunaan aplikasi WA untuk pengumpulan tugas (subtitution) } \\
\text { - Penggunaan aplikasi canva untuk membuat poster (augmentation) }\end{array}$ \\
\hline $\mathrm{C}$ & $\begin{array}{l}\text { - Penggunaan power point untuk menyampaikan materi. Hanya gambar dan } \\
\text { informasi teks yang terdapat di power point (subtitution) } \\
\text { - Penggunaan gform untuk mengevaluasi capaian pembelajaran (subtitution) } \\
\text { - Pengisian LKPD dengan format yang diberikan melalui WA (subtitution) }\end{array}$ \\
\hline & $\begin{array}{l}\text { - Penggunaan power point untuk menyampaikan materi. Selain gambar dan teks, } \\
\text { terdapat video pada power point (subtitution) }\end{array}$ \\
\hline $\mathrm{D}$ & $\begin{array}{l}\text { - Penggunaan gform untuk mengevaluasi capaian pembelajaran (subtitution) } \\
\text { - Pengisian LKPD dengan format yang diberikan melalui google classroon } \\
\text { (subtitution) }\end{array}$ \\
\hline $\mathrm{E}$ & $\begin{array}{l}\text { - Penggunaan power point untuk menyampaikan materi. Hanya gambar dan teks, } \\
\text { yang terdapat pada power point (subtitution) } \\
\text { - Penggunaan gform untuk mengevaluasi capaian pembelajaran (subtitution) } \\
\text { - Pengisian LKPD dengan format yang diberikan melalui WA (subtitution) }\end{array}$ \\
\hline $\mathrm{F}$ & $\begin{array}{l}\text { - Penggunaan power point untuk menyampaikan materi. Hanya gambar dan teks, } \\
\text { yang terdapat pada power point (subtitution) } \\
\text { - Penggunaan gform untuk mengevaluasi capaian pembelajaran (subtitution) } \\
\text { - Pengisian LKPD dengan format yang diberikan melalui WA (subtitution) }\end{array}$ \\
\hline
\end{tabular}

Tabel 2 menunjukan penggunaan teknologi yang digunakan calon guru dalm simulasi pembelajaran. Pada saat penyampaian materi atau pendahuluan semuanya menggunakan power point. Bentuk informasi pada power point hanya berupa teks dan gambar. Hanya ada satu yang memasukan video dalam power point. Penggunaan teks dan gambar merupakan hal yang biasa dilakukan dalam tatap muka. Berarti tidak peningkatan fungsional dari teknologi yang digunakan. Interaksi peserta didik dengan guru kurang terbangun dengan media ini. Penggunaan aplikasi lain yang memungkinkan terjadinya interaksi lebih luas dalam materi menjadi salah satu cara untuk meningkatkan fungsional teknologi dalam pembelajaran. Minalti \& Erita (2021) mengatakan bahwa penggunaan aplikasi nearpod dapat membuat peserta didik lebih aktif dan tertarik dalam pembelajaran daring dan guru dapat memantau kemajuan peserta didik dengan leluasa. Salsabila et al. (2020) menyatakan aplikasi quizizz dapat digunakan sebagai media untuk pembelajaran berbasis permainan yang dapat meningkatkan perhatian dan keaktifan peserta didik dalam pembelajaran. Optimalisasi aplikasi pada pembelajaran daring yang bisa meningkatkan interaksi peserta didik dengan temannya dan guru menjadi hal yang dapat dipertimbangkan dalam meningkatkan fungsi teknologi dalam pembelajaran.

Pada kegiatan eksplorasi, peserta didik melakukan kegiatan dalam kelompok tetapi menggunakan media yang berbeda. Empat dari enam partisipan mengkondisikan peserta didik berkolaborasi dengan mengisi LKPD yang telah disediakan oleh guru. Pemanfaatan teknologi pada kegiatan ini tidak ada peningkatan secara fungsional, sama seperti halnya siswa diberi LKPD dan mengisi menggunakan 
pulpen. Dua partisipan lainnya menggunakan teknologi dengan adanya peningkatan fungsional. Yang pertama adalah penggunaan aplikasi yang mensimulasikan pengukuran. Peningkatannya adalah pada kegiatan ini, peserta didik dapat mengevaluasi cara penggunaan, pembacaan alat ukur sendiri serta mengatur kecepatan belajar. Pada kegiatan ini, peserta didik akan mencoba dan tahu sendiri bahwa pemahamannya sudah benar atau belum. Penggunaan simulasi berbasis teknologi dalam pembelajaran dapat meningkatkan kualitas pembelajaran, motivasi, dan hasil belajar peserta didik (Larasati \& Sukisno, 2014). Yang kedua adalah penggunaan aplikasi canva untuk membuat poster. Penggunaan aplikasi ini dapat memberikan kesempatan kepada peserta didik untuk membuat poster yang lebih menarik dan bermakna karena di dalamnya tersedia desin yang menarik dan fitur yang mendukung (Junaedi,2021)

Evaluasi pembelajaran dilakukan dengan menggunakan google form dan quizizz. Pertanyaan yang dibuat berbentuk pilihan ganda. Penggunaan teknologi pada tugas ini termasuk subtitution. Kegiatan ini masih dapat tergantikan dengan teknologi lama, yaitu pensil dan kertas. Peningkatan fungsional dari google forms maupun quizizz dapat dilakukan dengan menambahkan video pada soal, mengontrol kuis dari jauh seperti siswa diminta mengerjakan kuis di rumah sebelum masuk pembelajaran dan hasilnya dijadikan acuan pada saat pembelajaran (Castro, 2018).

Berdasarkan uraian di atas, tingkat penggunaan teknologi dalam pembelajaran yang dilakukan oleh calon guru IPA dominan pada kategori subtitution. Pada kategori ini, teknologi hanya sebagai pengganti dan belum ada peningkatan fungsional dari teknologi. Fungsi dari teknologi sebagai cara baru dalam mempelajari hal baru belum teroptimalisasi dengan baik dan cara mengajar guru masih sama. Padahal penggunaan teknologi dalam pembelajaran diharapkan dapat mengubah cara mengajar guru (Suyamto et al.,2020). Pembelajaran yang efektif membutuhkan pengembangan bagaimana materi pelajaran dapat dimodifikasi menggunakan teknologi yang berbeda (Juanda, A et al, 2021).

\section{Simpulan}

Dari paparan di atas dapat disimpulkan bahwa calon guru IPA telah mampu menggunakan beberapa platform digital dalam pembelajaran. Namun, optimalisasi fungsi teknologi dalam pembelajaran belum maksimal. Perlu pelatihan bagi calon guru IPA bagaimana teknologi dapat berperan lebih optimal dalam proses pembelajaran.

\section{Ucapan terima kasih (optional)}

Ucapan terima kasih digunakan untuk memberikan apresiasi kepada pihak-pihak yang berperan dalam penelitian/artikel, baik dalam bentuk support dana, perizinan, konsultan maupun tim yang berperan dalam membantu pengambilan data.

\section{Referensi}

Ahmad, N., et al. (2021). The Effect Of Interactive Computer Animation And Simulation On Students' Achievement And Motivation In Learning Electrochemistry. JPII 10 (3) (2021) 311-324.

Castro, S. (2018). Google Forms Quizzes and Substitution, Augmentation, Modification, and Redefinition (SAMR) Model Integration. Issues and Trends in Educational Technology Volume 6, No.2.

Chaeroni, Y. et al. (2019). Penerapan I-Spring Suite 8 Pada Model Pembelajaran Improve Untuk Meningkatkan Kemampuan Pemahaman Dan Pemecahan Masalah Matematis Peserta Didik Pada Pokok Bahasan Program Linear Di Tingkat Sekolah Menengah. Jurnal Kehumasan Universitas Pendidikan Indonesia Volume 2, Nomor 2.

Effendi, D., \& Wahidy, A. (2019). Pemanfaatan Teknologi Dalam Proses Pembelajaran Menuju Pembelajaran Abad 21. Prosiding Seminar Nasional Pendidikan Program Pascasarjana Universitas Pgri Palembang. 
Elliniawat, E. et al. (2021). Face-to-face mode vs. Online mode: a discrepancy in analogy-based learning during covid-19 pandemic. JPII 10 (3) (2021) 368-377.

http://www.hippasus.com/rrpweblog/archives/2014/12/11/SAMRandTPCK_HandsOnApproachClassr oomPractice.pdf

Hunter, J. (2015). Technology integration and high possibility classrooms: Building from TPACK. Routledge.

Juanda, A., et al. (2021). Teacher Learning Management: Investigating Biology Teachers' TPACK To Conduct Learning During The Covid-19 Outbreak. JPII 10 (1) (2021) 48-59.

Junaedi, S. (2021). Aplikasi Canva Sebagai Media Pembelajaran Daring Untuk Meningkatkan Kemampuan Kreatifitas Mahasiswa Pada Mata Kuliah English For Information Communication And Technology. Bangun Rekaprima Vol.07/2.

Larasati, D. \& Sukisno, M. (2014). Penggunaan Media Simulasi Berbasis Teknologi Informasi Dalam Pembelajaran Fisika Pada Siswa Lintas Minat Di Sma Negeri 3 Pekalongan. Unnes Physic Education Journal 3 (3).

Minalti, M \& Erita, Y. (2021). Penggunaan Aplikasi Nearpod Untuk Bahan Ajar Pembelajaran Tematik Terpadu Tema 8 Subtema 1 Pembelajaran 3 Kelas IV Sekolah Dasar. Journal of Basic Education Studies Volume 4 Nomor 1.

Muktiarni. (2021). Integration of The SAMR Learning Model In Vocational Education. Jurnal UPI Volume 10 Issue 1, Hal 83-88.

Muliadi, A., Prayogi, S., Bahalwan, F., Nirmala, W., \& Verawati, N. (2021). Online Learning During the Covid-19 Pandemic: Preservice Teacher's Perception. Jurnal Penelitian Pendidikan IPA, 7(3), 464467.

Niswatin, K. \& Zainiyaiti, H. (2020). Implementasi Model SAMR (Substitution, Augmentation, Modification, Redefinition) di MI Al-Ishlah Glagah Lamongan. Tadris Jurnal Pendidikan Islam.

Nurmalahayati, N., Salmiati, A., \& Izasatifa, B. (2022). Analysis of the Covid-19 Learning Process and Knowledge Integration in the Education Unit. Jurnal Penelitian Pendidikan IPA, 8(1), 140-146.

Nuryani, D. \& Handayani, I. (2020). Kompetensi Guru Di Era 4.0 Dalam Meningkatkan Mutu Pendidikan. Prosiding Seminar Nasional Pendidikan Program Pascasarjana Universitas PGRI Palembang.

Puentedura, R. R. (2014a). SAMR and TPCK: A Hands-On Approach to Classroom Practice. Ruben R. Puentedura's Weblog. Diakses tanggal 2 Januari 2022 dari.

Purnasari, P.,\& Sadewo, Y. (2020). Pemanfaatan Teknologi Dalam Pembelajaran Sebagai Upaya Peningkatan Kompetensi Pedagogik. Jurnal Publikasi Pendidikan Volume 10 Nomor 3.

Salsabila, U. et al. (2020). Pemanfaatan Aplikasi Quizizz Sebagai Media Pembelajaran Ditengah Pandemi Pada Siswa SMA. Jurnal Ilmiah Ilmu Terapan Univeristas Jambi Vol. 4 No.2.

Savignano, M. A. (2017). Educators' Percpetions of the Substitution, Augmentation, Modification, Redefinition Model for Technology Integration. University of Northern Colorado.

Suminar, D. (2019). Penerapan Teknologi Sebagai Media Pembelajaran Pada Mata Pelajaran Sosiologi. Prosiding Seminar Nasional Pendidikan FKIP Universitas Sultan Ageng Tirtayasa Vol. 2, No.1, 2019, hal. 774-783. 
Suyamto, J., et al. (2020). Analisis Kemampuan Tpack (Technolgical, Pedagogical, And Content, Knowledge) Guru Biologi Sma Dalam Menyusun Perangkat Pembelajaran Materi Sistem Peredaran Darah. INKUIRI : Jurnal Pendidikan IPA Vol. 9 No.1.

Zainal, M. (2020). Integrasi Model SAMR (Subtitution, Augmentation, Modification, and Redefinition) pada Diklat Jarak Jauh Balai Diklat Keagamaan Makassar. Jurnal Widyaiswara Indonesia Vol. 1, No. 3, pp. 155-163. 